ПОЛІТИЧНІ ПРОБЛЕМИ МІЖНАРОДНИХ ВІДНОСИН

УДК: 327:061.1€С

\title{
GOALS AND PRINCIPLES IN PARTNERSHIP RELATIONS BETWEEN THE EU AND THE AFRICAN UNION
}

\section{ЦІЛІ ТА ПРИНЦИПИ ПАРТНЕРСТВА У ВІДНОСИНАХ МІЖ СС ТА АФРИКАНСЬКИМ СОЮЗОМ}

\section{ЦЕЛИ И ПРИНЦИПЫ ПАРТНЕРСТВА В ОТНОШЕНИЯХ МЕЖДУ ЕС И АФРИКАНСКИМ СОЮЗОМ}

\section{Tolstov S. V.}

$\mathrm{PhD}$ in History, Associate-professor, Head of the Department of Transatlantic Studies at the Institute of World History, National Academy of Sciences of Ukraine. E-mail: conf_iweir@ukr.net

\section{Толстов С. В.}

Кандидат історичних наук, доцент, завідувач відділу трансатлантичних досліджень Державної установи «Інститут всесвітньої історії НАН України». Електронна пошта: conf_iweir@ukr.net

\section{Толстов С. В.}

Кандидат исторических наук, доцент, заведующий отделом трансатлантических исследований Государственного учреждения «Институт всемирной истории НАН Украины». Электронная почта: conf_iweir@ukr.net

\begin{abstract}
The African continent has traditionally been considered as Europe's 'backyard'. The Africa - EU partnership framework was established at the Africa-EU Summit in Cairo in 2000. In 2005 the European Commission issued a renovated EU Strategy for Africa aimed to establish a Euro-African pact to accelerate Africa's development. Since then a considerable change has taken place on both continents, which challenge the way Africa and Europe perceive each other. On $29^{\text {th }}$ June 2016 the African Union Commission and the EU signed the third phase of the African Union Support Programme.

The goals of the EU-AU strategic partnership relations envisage a wide range of priorities in different areas including enhanced political dialogue, development assistance, joint management and joint responsibility, security cooperation, regulation of migrations, promotion of trans-regional projects etc. The joint EU-AU documents strengthen upon bilateral cooperation in addressing global issues, distributing burdens, mutual accountability, solidarity and mutual trust, equality and justice, respect for international law and agreements, gender equality and non-discrimination. However the actual results of interaction in such priority areas as peace and security, democracy, good governance and human rights, sustainable and inclusive development, economic growth, human development and continental integration remain rather low. Thus the European political experts often speculate on the ineffectiveness of the EU's concept of normative power and external governance attempts in relation to the African states.

Key words: European Union, African Union, strategic partnership, trade, normative power, Joint Africa - EU Strategy.
\end{abstract}


Анотація. У минулому Африканський континент традиційно вважався «заднім двором» європейських колоніальних імперій. Згодом механізм партнерства Африка-СС був закладений на саміті Африка - СС в Каїрі в 2000 р. У 2005 р. Свропейська Комісія опублікувала оновлену стратегію ЄС щодо Африки, спрямовану на створення євро-африканської пакту для прискорення розвитку Африки. 3 того часу на обох континентах відбулися значні зміни, які зумовили перегляд підходів у взаєминах між СС і Африканським Союзом. 29 червня 2016 р. Комісія Африканського Союзу та ЄС підписали третій етап «Програми підтримки Африканського Союзу».

Цілі відносин стратегічного партнерства між ЄС і Африканським Союзом передбачають широке коло пріоритетів у різних галузях, у т. ч. активізацію політичного діалогу, допомогу в цілях розвитку, спільне управління і спільну відповідальність, співпрацю в сфері безпеки, регулювання міграчій, сприяння трансрегіональні проектам і т. n. Спільні документи $Є C$ і АС орієнтовані на зміџнення двостороннього співробітництва у вирішенні глобальних проблем, розподіл витрат, взаємну підзвітність, солідарність і взаємну довіру, рівність і справедливість, повагу до міжнародного права і угод, гендерну рівність та недискримінацію. Однак фактичні результати взаємодії в таких пріоритетних галузях, як забезпечення миру $і$ безпеки, сприяння демократії, добре управління, права людини, сталий $і$ всебічний розвиток, економічне зростання, розвиток людського потенціалу та континентальна інтеграція залишаються досить низькими. Узв'язку з иим європейські політичні експерти відзначають низьку ефективність концепиії «нормативної влади» ЄC і спроб застосування елементів зовнішнього управління щодо африканських держав.

Ключові слова: Свропейський Союз, Африканський Союз, стратегічне партнерство, торгівля, нормативне вплив, Спільна стратегія Африка- $С С$.

Аннотация. В прошлом Африканский континент традиционно считался «задним двором» европейских колониальных империй. Механизм партнерства Африка-ЕС был заложен на саммите Африка - ЕС в Каире в 2000 г. В 2005 г. Европейская Комиссия опубликовала обновленную стратегию ЕС в отношении Африки, направленную на создание евро-африканского пакта для ускорения развития Африки. С тех пор на обоих континентах произошли значительные изменения, которые обусловили значительные изменения во взаимоотношениях между ЕС и Африканским Союзом. 29 июня 2016 г. Комиссия Африканского Союза и ЕС подписали третий этап «Программы поддержки Африканского Союза».

Цели отнотений стратегического партнерства между ЕС и Африканским Союзом предусматривают широкий круг приоритетов в различных областях, в том числе активизацию политического диалога, помощь в целях развития, совместное управление и совместную ответственность, сотрудничество в сфере безопасности, регулирование миграций, содействие трансрегиональным проектам и т. д. Совместные документы ЕС и АС ориентированы на укрепление двустороннего сотрудничества в решении глобальных проблем, распределение расходов, взаимную подотчетность, солидарность и взаимное доверие, равенство и справедливость, уважение международного права и соглашений, гендерное равенство и недискриминацию. Однако фактические результаты взаимодействия в таких приоритетных областях, как обеспечение мира и безопасности, содействие демократии, хорошее управление, права человека, устойчивое и всестороннее развитие, экономический рост, развитие человеческого потенциала и континентальная интеграция остаются достаточно низкими. В связи с этим европейские политические эксперты отмечают низкую эффективность концепџии «нормативной власти» ЕС и попыток применения элементов внешнего управления в отношении африканских государств. 
Ключевые слова: Европейский Союз, Африканский Союз, стратегическое партнерство, торговля, нормативное влияние, Совместная стратегия Африка-EC.

Modes of EU partnerships. In its external activities the European Union widely uses such a tool as strategic partnership relations with the leading countries and multilateral organizations. Development of strategic partnerships was envisaged by the European Security Strategy, adopted in 2003. Among the objectives and guidelines this document mentioned the EU's strategic partnership with the US and Russia and anticipated the establishment of such formats of cooperation with Japan, China, Canada, India and several other countries and integration communities that share goals and values of the EU and are ready to act in their support.

At first, the strategic partnership format envisaged modernization of relations with a variety of important actors which previously were based on cooperation agreements between these countries and the European Community. The 2008 review of 'European Security Strategy' suggested that bilateralism is compatible with multilateralism. The document clarified that strategic partnership was developed specifically in the pursuit of effective multilateral objective, and parallel to (inter-)regionalism. It has defined Brazil and South African Republic as the EU strategic partners and declared the importance to develop relations of the EU with the countries of Latin America, Africa, ASEAN, SAARC and Central Asia.

The latest EU documents mentioned 10 countries (Brazil, Canada, China, India, Mexico, Japan, South Korea, Russia, South Africa and the United States) as the strategic partners together with the African Union, the Community of Latin American and Caribbean States (in Spanish: Comunidad de Estados Latinoamericanos y Caribeños, CELAC) and NATO. The institutional forms of strategic partnership relations between the EU and Russia were suspended in spring 2014.

The EU has traditionally paid close attention to relations with Africa. Some EU countries, especially France and Britain, retain their own infrastructure of bilateral relations with the most of their former colonies. However, along with bilateral formats of relations, the multilateral dialogue between the EU and Africa is considered to be one of the leading directions of the common foreign policy of the EU as an international actor. At present the main organizational format of relations is the multilateral interinstitutional dialogue of the EU with the African Union (AU).

The most of contemporary research on the EU - African relations explore a comparative analysis of traditional interests and normative power elements in the external policies of the European Union. Different versions of this approach are noticeable in the books and papers by M. Brosig (Brosig, 2011), M. Farrell (Farrell, 2005), J. Orbie (Orbie, 2009), S. Scheipers \& D. Sicurelli (Scheipers and Sicurelli, 2008; Sicurelli, 2013), U. Staeger (Staeger, 2016) and other European scholars.

Another significant dimension of research interests is related with the development policy and the EU's external action (Farrell, 2010; Olsen, 2013; Orbie and Carbone, 2016; Smith, 2013).

Specific reflections of the EU's trade policy and growing competition between the EU and China have also become a constant matter of analysis by the political scientists in the EU member states and the U.S. (Damro, 2012; Grauls and Stahl, 2010; Meunier and Nicolaïdis, 2006; Sbragia, 2010; Stahl, 2011).

This article focuses on the tasks, principles and contents of strategic partnership relations established between the EU and the African Union.

Key research ideas. The process of implementation of the EU's foreign policy organizationally divides the African countries into two macro-regional groups - the Sub-Saharan and South Mediterranean. Comparatively more attention is paid to the Mediterranean countries. The 
countries of Southern Mediterranean which are considered to be the EU's neighbours are covered by the European Neighbourhood Policy programs with a separate budget.

The European institutions interact through different forms of dialogue with the African countries, e.g. (1) relations within the partnership agreement between the African, Caribbean and Pacific (ACP) Group of States and the European Community and its Member States (the Cotonou Agreement, concluded for the period of up to 2020); (2) intercontinental multilateral interaction in the form of partnership between the EU and the AU, which is designated as strategic; (3) bilateral cooperation under the Agreement on Development and Cooperation between the Republic of South Africa and the European Community and its Member States.

Since 2000 the EU launched a practice of holding joint summits with the African countries, which have been held on a regular basis since 2007. The EU recognised the African Union as an important institutional partner and a 'natural counterpart' for continental issues. The recognition of the AU's institutional role should facilitate the implementation of common EU strategy in relations with the African states. The EU governing institutions laid expectations on the AU's coordinating function in the implementation of joint programs, including the allocation and the use of funds. In order to ensure direct contacts the EU opened its representation at the AU headquarters in Addis Ababa and expressed its consent to "support the strengthening of the institutional ability of the AU to interact with the EU and other international partners" ( $A$ Joint Africa-EU Strategy, 2007: 22).

The European governing institutions use different political tools in relations with the developing countries. The Cotonou Agreement (2000) with 79 ACP states is considered to be the most general format. This dimension of EU foreign activities is funded by the European Development Fund (EDF), which is intergovernmental in nature and remains outside the EU budget, despite the fact that most of its resources are managed by the European Commission.

Meanwhile, the European institutions formulate and adopt special regional strategies. As far as Africa is concerned, the Joint Africa - EU Strategy (JAES) signed in Lisbon in December 2007 serves as a regional political instrument between the EU, the African Union and its 54 member states. The objectives of the Joint Africa - EU Strategy interpret the task of relations in a broader sense than cooperation with a view to promote development. JAES claims that intercontinental partnership "will be based on the Euro-African consensus on values, common interests and common strategic objectives. This partnership should strive to bridge the gap in the levels of development between Africa and Europe by strengthening economic cooperation and promoting sustainable development on both continents, living side by side in peace, security, prosperity, solidarity and human dignity" (A Joint Africa - EU Strategy, 2007: 2).

The "enhanced political dialogue, joint management and joint responsibility" should be used as the main instruments of partnership. They should ensure bilateral collaboration and cooperation in addressing global issues, distributing burdens (expenses), mutual accountability, solidarity and mutual trust, equality and justice, overall safety and security of the person, respect for international law and agreements, gender equality and non-discrimination and, not at the least, the focus on the long-term approach (A Joint Africa - EU Strategy, 2007: 2).

The joint EU - AU documents declared intentions to step up relations in such areas such as trade, regulation of global issues including migrations and climate changes, promotion of African countries in finding "trans-regional and continental responses" to today's important problems and tasks. The most important topics of the bilateral dialogue include peace and security. In addition, there is a growing attention to the socio-economic aspects. It includes the creation of jobs in the legal sector of the African economies and the development of partnerships, oriented on people's interests, including ensuring a wider participation of African and European citizens in it. 
The Joint Africa - EU Strategy outlined four strategic priorities that reveal the goals of partnership. They include:

a) "Peace and Security", which envisage strengthening peace and security architecture of the African continent. Under this service line since 2004 the EU has allocated more than $€ 1.1$ billion to the African Peace Facility. This funding provides financial assistance to various peacekeeping operations in Africa, including the African Union mission in Somalia (AMISOM) and the African-Led International Support Mission in Mali (AFISMA), launched in the first half of 2013 (A Joint Africa - EU Strategy, 2007: 5-7).

b) "Democratic Governance and Human Rights." The AU- EU dialogue on these issues began in 2008 within a separate platform. Up to early 2014 the EU and the AU held 10 rounds of dialogue on human rights dealing with peace and security, position of women and children in conflicts, election observations, execution of death penalty, rights of migrants, business law, human rights and fight against impunity (A Joint Africa - EU Strategy, 2007: 8-10).

c) "Trade and Regional Integration". This dimension touches upon the dialogue between the EU and the AU on the issues of regional economic integration. Under this area the EU renders assistance through its EU - Africa Infrastructure Trust Fund. The EU-Africa Infrastructure Partnership has to promote interconnectivity of African infrastructure at all levels. Cooperation between the EU-Africa Infrastructure Trust Fund and the Pan-African Infrastructure Development Fund was initiated to support interconnectivity across the continent and its different regions and tackle the issue of delivery of infrastructure services (A Joint Africa - EU Strategy, 2007: 10-12, 18).

d) "Key Development Issues" envisage the achievement of sustainable economic growth and equitable social development according to the African regional priorities formulated at the summits and conferences on the implementation of the UN Millennium Development Goals ('MDGs'). They relate to reducing poverty and hunger, universal primary education, providing the population with clean drinking water, increasing life expectancy etc. However, despite some progress the envisaged goals were not achieved until their review in 2015-2016 (A Joint Africa - EU Strategy, 2007: 13-21).

Most of economic issues (except trade and integration) and all the issues of socio-economic and humanitarian character are attributed to the dimension of "Key Development Issues." They contain a number of thematic blocks such as development cooperation, human and social development, gender equality, environmental sustainability and climate change, migration and development, agriculture and food security, infrastructure, water supply and sanitation, energy, development of knowledge-based societies, cultural cooperation and development of communication.

A separate unit "Energy" is dedicated to the access to energy resources and its sustainable management. It envisages improved access to services providing a reliable, secure, affordable and sustainable energy for consumers on both continents. In 2010 the first high-level meeting on this occasion determined the political objectives for the period until 2020, including the supply of 100 million consumers in Africa with modern sustainable energy.

Environmental cooperation should be based on common agenda on climate change, desertification and political support for the initiatives supporting environmental policy in Africa.

In relations with the AU the European institutions regard the issues of "Migration, mobility and employment" as one of their top priorities. The European executive bodies agreed to support the African Institute for remittances, which should promote African public and private subjects in using more effective remittances as an important means of promoting development. This type of partnership also envisages supporting 'Nyerere program' which promotes the development of human resources in Africa by providing academic mobility. 
The "Science, Information society and Space" dimension determines the EU - pan-African political dialogue on science, technology and innovation. Activities in this direction stated in 2011. The European Commission launched support for programs of research grants to the African Union and opened access for African researchers to the EU $7^{\text {th }}$ Framework Programme for Research and Technological Development (FP7).

Touching the issues of human and social development the partners promised to turn attention at the problems of employment and social protection in particular, the shortage of employment opportunities, promotion of decent work in Africa with priority being given to creating productive jobs in the formal (i.e. legal) economy, improving poor living and working conditions in line with the UN decent work agenda and integrating the informal economy into the formal one. The AU and the EU intended to develop "technology of employment" and to adapt infrastructure to the creation of jobs for both skilled and unskilled Africans. It was promised to promote investment in the private sector, taking into account, in particular, the employment of youth and women in the service sector (A Joint Africa - EU Strategy, 2007: 14).

The AU and the EU recognized the necessity to improve communications at the level of institutions, non-governmental organizations and citizens and more effectively promote social and cultural values of the European and African nations. In this regard, the AU and the EU expressed their intention to promote more accurate images of each other, and fight negative stereotypes, xenophobia and racism. This should be achieved through enhanced exchanges and contacts of non-state actors, including trade unions, professional associations, the private sector, media, schools, universities, research and cultural institutions, and sport clubs and associations, including through support for twinning arrangements between civil society organizations ( $A$ Joint Africa - EU Strategy, 2007: 20-21; Ramet, 2016).

The general management and coordination of partnerships within the main thematic dimensions is determined by the three-year plans, which have been implemented since 2008, as well as through the joint solutions adopted by summits and annual joint meetings of the European Commission and the African Union Commission.

According to the OECD data, the African countries are the recipients of more than a half of the volume of EU international aid. The main bulk of funds for international development are being transferred through the European Development Fund, tied to the Cotonou Agreement with the ACP states. The tenth budget of the Fund (2008 - 2013) which is formed separately from the common EU budget amounted to $€ 22.7$ billion. In June 2013 the joint ACP - EU Council of Ministers agreed upon a financial package for $2014-2020$ with the amount of $€ 31.5$ billion. The most of these funds will be supplied through the eleventh budget of the European Development Fund which accounts for $€ 29.1$ billion. It includes $€ 24.3$ billion for national and regional programs, $€ 3.6$ billion for intra-ACP cooperation and $€ 1.1$ billion for the ACP Investment Facility, run by the European Investment Bank (Ramet, 2016).

Since December 2011 the implementation of JAES was supported by the Development Cooperation Instrument (DCI). The DCI budget for 2014 - 2020 allocates $€ 845$ million to the PanAfrican Programme (PANAF), which was created to fund the JAES and continental and transcontinental activities. Unlike the European Development Fund (EDF), the financing of the Development Cooperation Instrument is carried out from the EU regular seven-year budget. Other financial instruments which cover Africa include the European Neighbourhood Instrument for North Africa, DCI thematic instruments (Global Public Goods and Challenges and Civil Society and Local Authorities), and the European Instrument for Democracy and Human Rights (EIDHR).

In 2004 the European Commission set up the African Peace Facility as a special fund for the financing of conflict prevention, management and resolution activities in Africa. The EU is the 
main donor of the budget of AU's peacekeeping operations which is for $90 \%$ financed from the external sources. The EU supports African Standby Force and promotes the improvement of their training. French and African peacekeeping units perform their functions in Mali and the Central African Republic.

The fourth EU-Africa summit (Brussels, 2 - 3 April 2014) adopted a political declaration by heads of state and government and a results-oriented roadmap for 2014-2017. The roadmap refocused the initial eight thematic partnerships around five priority areas: (i) peace and security; (ii) democracy, good governance and human rights; (iii) human development; (iv) sustainable and inclusive development and growth and continental integration; (v) global and emerging issues. In this new cooperation framework, science, technology and innovation were recognised as a cross-cutting issue, in view of their contribution to the attainment of all other socio-economic development objectives.

In addition to the joint political declaration the summit adopted a separate declaration on migration and mobility, which contains a detailed action plan to combat illegal immigration and human trafficking. Among the main tasks the declaration mentioned the intention to improve the international protection of migrants, promote better organization of legal migration and pay more attention to the interconnection between migration and development (EU-Africa Declaration, 2014). In the context of the migration crisis in the EU in $2014-2015$ this topic became a dominant issue in the EU - Africa relations.

The EU foreign policy agenda considers migration issues as the first priority issue, especially with the North African countries and Turkey. The countries of North Africa act both as a source and one of the main routes of transit of illegal migrants and refugees. Turkey is mostly considered as a major transit country for the Balkan route of illegal immigration to the EU. However, the immigrants from Sub-Saharan Africa comprise a significant part of illegal and economic migrants to the EU.

The European institutions consider their main task in the regulation of migration countering the penetration of illegal or irregular migrants and preventing mass migration waves caused by social problems, climate and natural disasters and armed conflicts. The European institutions declared that the regulation of migration and prevention of mass immigration flows would be correlated with the rendering foreign assistance to the African states. Nevertheless, the general results of the efforts of the European Commission and the European External Action Service in this area look apparently abortive.

In economic relations with the Sub-Saharan countries the European Commission focuses on signing new economic partnership agreements. The Cotonou agreement between the EU and 79 ACP states is considered to be the basis for negotiations. It envisages a phased transition to the new trade regime in order to create a system based on the principles of reciprocity instead of unilateral trade preferences which contradict the WTO rules.

Negotiations on the new economic partnership agreements with the countries of the Economic Community of West African States (ECOWAS) and four countries of South African Development Community (SADC) have already been completed. The signing of the agreement between the EU and Botswana, Lesotho, Swaziland and Mozambique took place on June 10, 2016. Interim economic agreements of a new type were also concluded with some other states (Bierbrauer, 2016).

The EU relations with South Africa, Nigeria, Côte d'Ivoire, Cameroon, Morocco and Tunisia are considered to be the most successful. EU relations with South Africa, a SADC member, are based on a separate basis. According to the Agreement on trade, development and cooperation (1999) the EU and South Africa abolished 95\% and 85\% of customs tariffs respectively. 
In 2014 Africa accounted for around 9\% of both the imports to the EU-28 and the exports from the EU-28. This was far below Asia, which stood for $43 \%$ of the imports value to the EU28 and about a third of the exports value. Northern America only accounted for $14 \%$ of the imports to the EU-28 but was the destination for 21\% of the exports. In 2013 and 2014 the value of EU-28 imports from Africa decreased. It fell by 11\% in 2013 and by another 8\% from 2013 to 2014, reaching a lower value in 2014 than prior to the economic crisis (The European Union and the African Union, 2015: 18).

Conclusions. Recent trends in the EU relations with the African states reveal a number of significant features and contradictions:

- The EU recognized the AU as a leading partner in the intercontinental dialogue on key issues, including the political dialogue, promotion of development, democratic control, transit of migration, the maintenance of peace and security etc. By the scope of problems and the number of interactive formats EU-AU strategic partnership is a unique example in the world practice.

- The EU initiated a revision of trade relations with the African countries. This process includes negotiations, signing and application of the new economic partnership agreements with African subregional organizations or separate countries. These new agreements should be based on the WTO principles. Although the EU intends to preserve some trade preferences for the 49 poorest African countries, including quota-free and duty-free access of their products to the European market.

- The EU remains the main external sponsor of African countries, financing programs for development promotion and trying to correlate their socio-economic development. However, attempts to link the distribution of economic aid with migration control have not yet produce sufficient positive results. The most of African governments are still unable either to ensure the rapid growth of living standards, or to prevent the leakage of immigrants along the main transit roots to the EU.

- A nominal list of forms of political coordination in the African Union accedes the other regional political and economic communities, including the ASEAN, the Arab League, Mercosur, the Organization of American States, and South Asian Association for Regional Cooperation. However, except for peacekeeping operations, which prevent the spread of conflicts, the effectiveness of AU institutions in the most of areas remains low, thus limiting prospects for effective cooperation with the EU.

- Differences in the economic interests of external players, including the USA, the EU and China lead to a competition of impacts that affect the exacerbation of political struggle and cause violent change of power in some countries.

\section{References}

1. A Joint Africa - EU Strategy (2007). Brussels, Council of the European Union. 16344/07 (Presse 291). Available at: http://www.consilium.europa.eu/uedocs/cms_data/docs/pressdata/en/er/97496.pdf.

2. Bierbrauer, E. (2016). Trade regimes applicable to developing countries. Fact Sheets on the European Union. Available at: http://www.europarl.europa.eu/aboutparliament/en/displayFtu.html?ftuId=FTU_6.2.3.html.

3. Brosig, M. (2011). The Emerging Peace and Security Regime in Africa: The Role of the EU. European Foreign Affairs Review, 16 (1), pp. 107-122.

4. Damro, Ch. (2012). Market power Europe. Journal of European Public Policy, 19 (5), P. 682-699. 
5. EU - Africa Declaration on migration and mobility (2014). Fourth EU - Africa Summit. 2 - 3 April 2014, Brussels. Available at: http://www.consilium.europa.eu/en/press/press-releases/2014/04/pdf/fourth-eu-africa-summit-eu-africa-declaration-on-migration-and-mobility.

6. Farrell, M. (2005). A Triumph of Realism over Idealism? Cooperation Between the European Union and Africa. Journal of European Integration, 27 (3), P. 263-283.

7. Farrell, M. (2010). Bridging the gap between EU, Mediterranean and Africa relations: Partnership, governance and (re)-evolving relations. L'Europe en Formation, (356), P. 169-191.

8. Grauls, S. and Stahl A. (2010). European development policy towards sub-Saharan Africa: Challenges of the growing Chinese presence. Émulations, (7) [online]. Available at: http://www.revue-emulations.net/archives/n7/grauls.

9. Meunier, S. and Nicolaïdis, K. (2006). The European Union as a conflicted trade power. Journal of European Public Policy, 13 (6), P. 906-925.

10. Olsen, G. R. (2013). The European Union's Africa Policy: The Result of Nordicization or Europeanization? Journal of European Integration, 35 (4), P. 409-424.

11. Orbie, J. (2009). Europe's Global Role: External Policies of the European Union. Aldershot: Ashgate.

12. Orbie, J. and Carbone, M. (2016). The Europeanisation of development policy. European Politics and Society, 17 (1), P. 1-11.

13. Ramet, V. (2016). Africa. Fact Sheets on the European Union. Available at: http://www.europarl.europa.eu/aboutparliament/en/displayFtu.html?ftuId=FTU_6.6.5.html.

14. Sbragia, A. (2010). The EU, the US, and trade policy: competitive interdependence in the management of globalization. Journal of European Public Policy, 17 (3), P. 368-382.

15. Scheipers, S. and Sicurelli, D. (2008). Empowering Africa: normative power in EU - Africa relations. Journal of European Public Policy, 15 (4), P. 607-623.

16. Sicurelli, D. (2013). The European Union's Africa Policies: Norms, Interests, and Impact. Milton Park, Abingdon: Routledge.

17. Smith, M. (2013). Foreign policy and development in the post-Lisbon European Union. Cambridge Review of International Affairs, 26 (3), P. 519-535.

18. Staeger, U. (2016). Africa - EU Relations and Normative Power Europe: A Decolonial PanAfrican Critique. Journal of Common Market Studies, 54 (4), P. 981-998.

19. Stahl, A. K. (2011). The Impact of China's Rise on the EU's Geopolitical Reach and Interests in Africa. European Foreign Affairs Review, 16 (4), P. 427-446.

20. The European Union and the African Union (2015). A statistical portrait. 2015 ed. Luxembourg: Publications Office of the European Union. 